Ondokuz Mayıs Üniversitesi İlahiyat Fakültesi Dergisi, Ondokuz Mayıs University Review of the Faculty of Divinity e-ISSN: 2587-1854 OMUIFD, December 2019, 47: 211-239

İLAHIYAT FAKÜLTESi ÖĞRENCİLERININ
ÖĞRETMENLIK MESLEĞINE İLIŞKIN
TUTUMLARI İLE AKADEMIK ÖZYETERLIK ALGILARI: SİNOP ÖRNEĞI

The Perceptions of the StUdents' Academic SELF-EFFICACY AND THE ATTITUDES TOWARD THE TEACHING PROFESSION : SINOP SAMPLE

\author{
AYŞE İNAN KILIÇ \\ [Dr. Öğr. Üyesi, Sinop Üniversitesi, İlahiyat Fakültesi, Din Bilimleri ABD. \\ Assistant Professor, Sinop University, Theology Faculty, \\ Department of Sciences of Religious \\ ayseinank@hotmail.com \\ http://orcid.org/0000-0002-6079-7432] \\ Makale Bilgisi / Article Information \\ Makale Türü / Article Types: Araştırma Makalesi / Research Article \\ Geliş Tarihi / Received: 24 Eylül/September 2019 Kabul Tarihi / Accepted: 01 \\ Ekim/October2019 Yayın Tarihi / Published: 16 Aralı/December 2019
}

Yayın Sezonu / Pub Date Season: Aralı/December

Yll/Year: 2019 Sayl-Issue: $47 \quad$ Sayfa/211-239

\footnotetext{
Atıf/Cite as: Kılıç, Ayşe İnan. “i̇lahiyat Fakültesi Öğrencilerinin Öğretmenlik Mesleğine İlişkin Tutumları İle Akademik Özyeterlik Algıları: Sinop Örneği-The Perceptions of the Students' Academic Self-Efficacy and the Attitudes toward the Teaching Profession : Sinop Sample". Ondokuz Mayis Üniversitesi İlahiyat Fakültesi Dergisi- Ondokuz Mayıs University Review of the Faculty of Divinity 47 (Aralık-December 2019): 211-239. https://doi.org/ 10.17120/omuifd.624115

İntihal /Plagiarism: Bu makale, en az iki hakem tarafından incelendi ve intihal içermediği teyit edildi. / This article has been reviewed by at least two referees and scanned via a plagiarism software. http://dergipark.gov.tr/omuifd

Copyright (C) Published by Ondokuz Mayıs Üniversitesi, İlahiyat Fakültesi - Ondokuz Mayıs University, Faculty of Divinity, Samsun, Turkey. All rights reserved.
} 


\section{İlahiyat Fakültesi Öğrencilerinin Öğretmenlik Mesleğine İlişkin Tutumları ile Akademik Özyeterlik Algıları: Sinop Örneği}

Öz: Bu araştırmanın amacı İlahiyat Fakültesi son sınıf öğrencilerinin öğretmenlik mesleğine yönelik tutumları ile akademik özyeterlikleri arasındaki ilişkiyi incelemektir. Araştırmanın çalışma grubunu Sinop Üniversitesi İlahiyat Fakültesinin son sınıfında okuyan 209 öğrenci oluşturmaktadır. Araştırma sonucuna göre öğrencilerin öğretmenlik mesleğine yönelik tutumları oldukça yüksek iken akademik özyeterlik algıları orta seviyededir. Ayrıca öğrencilerin meslek tutumları ile akademik özyeterlikleri arasında pozitif ve istatistiki açıdan anlamlı korelasyon bulunmaktadır. ( $r=0,26 ; \mathrm{p}<0,001)$. Öğretmenlik mesleğine yönelik tutum ile mezuniyet sonrası yapılmak istenen meslek, fakülteyi tercih nedeni ve mezun olunan ortaöğretim türü arasında istatistiki açıdan anlamlı bir ilişki vardır. Öğretmenlik mesleğine yönelik tutum ile cinsiyet, ekonomik durum, yerleşim yeri, hazırlık okuma durumu ve öğrencilerin not ortalamaları değişkenleri arasında istatistiki açıdan anlamlı bir ilişki bulunamamıştır. Yine öğrencilerin özyeterlik puanı ile cinsiyet, ekonomik gelir, yerleşim yeri, mezun olunan ortaöğretim türü, hazırlık okuma, fakülteyi tercih nedeni, yapılmak istenen meslek, not ortalaması arasında istatistiki açıdan anlamlı bir ilişki bulunamamıştır.

Anahtar Sözcükler: Din Eğitimi, İlahiyat Fakültesi, Özyeterlik, Akademik Özyeterlik, Öğretmenlik Mesleğine Yönelik Tutum.

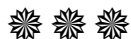

\section{The Perceptions of the Students' Academic Self-Efficacy and the Attitudes toward the Teaching Profession: Sinop Sample}

Abstract: The aim of this study is to investigate the relationship between the attitudes of the senior students of the Faculty of Theology toward teaching profession and their academic self-efficacy. The study group consists of 209 senior students in the Faculty of Theology at Sinop University. According to the results of the research, while students' attitudes towards teaching profession are quite high, their perceptions of academic self-efficacy are moderate. In addition, there is a positive and statistically significant correlation between students' professional attitudes and academic self-efficacy. ( $\mathrm{r}=$ $0.26 ; \mathrm{p}=0.000$ ). There is a statistically significant relationship between the attitude towards teaching profession and the type of secondary education that is graduated, the profession to be done after graduation, and the reason for choosing the faculty. No statistically significant relationship was found between the attitude towards teaching profession and the variables of gender, economic status, place of residence, preparatory reading status and students' averages. Also, no statistically significant difference was found between the students' self-efficacy score and gender, the economic 
ILAHIYAT FAKÜLTESi ÖĞRENCILERININ ÖĞRETMENLIK MESLEĞINE ILIŞKIN

TUTUMLARI ILE AKADEMIK ÖZYETERLIK ALGILARI: SINOP ÖRNEĞi

income, the place of residence, the type of secondary education graduated, preparatory reading, the reason for choosing the faculty, the profession required and the grade point average.

Keywords: Religious Education, Faculty of Theology, Self-efficacy, Academic SelfEfficacy, Attitude Towards Teaching Profession.

\section{釉}

\section{Giriş}

Bilindiği gibi Cumhuriyet tarihinin ilk dini yükseköğretim kurumu olan İlahiyat Fakültesi 1949 yılında Ankara'da kurulmuştur. Kuruluşundan itibaren din görevlisi ve din dersi öğretmeni yetiştiren bu kurum zaman içinde ülkenin din dersi öğretmeni ihtiyacını karşılama noktasında yetersiz kalınca, öğretmen yetiştirmek amacıyla Milli Eğitim Bakanlığına bağlı 4 yıllık Yüksek İslam Enstitüsü ve 1972 yılında İslami İlimler Fakültesi kurulmuştur. ${ }^{1} 1982$ yılında çıkarılan kararname ile diğer bütün öğretmen yetiştiren okullar ile birlikte bu iki kurum da üniversitelere bağlanmış ve İlahiyat Fakültesi adı altında teşkilatlanmıştır.. ${ }^{2} \mathrm{O}$ tarihlerden itibaren yıllarca din dersi ve meslek dersi öğretmenlerini yetiştiren İlahiyat Fakülteleri, 1997 yılında yeniden yapılandırılmıştır. Böylece bazı üniversitelerin İlahiyat Fakültelerinde İlköğretim Din Kültürü ve Ahlak Bilgisi (İDKAB) Öğretmenliği bölümü açılmış ve din dersi öğretmenleri bu bölümden mezun olanlar arasından atanmaya başlanmıştır. Fakat 2014 yılında İDKAB öğretmenliği bölümüne öğrenci alımı durdurulmuştur. Mevcut haliyle İlahiyat Fakülteleri örgün ve yaygın din eğitiminde görev yapan din eğitimcilerinin yetiştirildiği yükseköğretim kurumlarıdır. Bu fakültelerden mezun olan öğrenciler, Diyanet İşleri Başkanlığg'nda din hizmetleri alanında istihdam edildiği gibi ilköğretim ve liselerde din kültürü ve ahlak bilgisi, imam hatip okullarında da meslek dersleri öğretmeni olarak görev yapabilmektedirler.

Öğretmen niteliklerine yönelik yapılan pek çok araştırma, öğretmenlerin kişilik ve akademik özelliklerinin, ilgilerinin, tutumlarının ve davranışla-

1 Halis Ayhan, Türkiye'de Din Eğitimi, 3. Baskı (İstanbul: Dem Yayınları, 2014), 215-228.

2 Muhammed Şevki Aydın, Cumhuriyet Döneminde Din Eğitim Öğretmeni Yetiştirme ve İstihdamı (1923-1998) (Kayseri: İlahiyat Bilimleri Araştırma Vakfı Yayını, 2000), 110. 
rının öğretim sürecinde önemli rol üstlendiğini ortaya koymuştur. ${ }^{3} \mathrm{Bu}$ bağlamda öğretmenlerin akademik gelişimlerini etkileme gücüne sahip olan tutum ve özyeterlik kavramlarının öne çıktığı söylenebilir.

İlk kez sosyal öğrenme kuramı kapsamında kullanılan özyeterlik kavramı kişinin herhangi bir konuda ortaya koyacağı davranış şekillerini düzenleme ve gerçekleştirme yeterliliğine olan inancıdır. ${ }^{4}$ İnsanın her alana yönelik özyeterlik algısı bulunduğundan farklı özyeterlik tanımları ortaya çıkmaktadır. Akademik alanda bireyin başarılı olmasına katkı sağlayabilecek boyut olan akademik özyeterlik, kişinin eğitim sürecinde başarılı olması için gerekli olan potansiyel ve performans özelliklerine ilişkin algısı olarak tarif edilmektedir. ${ }^{5}$ Bandura'nın özyeterlik kavramını ortaya attığı ilk anlardan itibaren yapılan araştırmalarda öğrencilerin akademik özyeterlik inançlarının akademik başarıyı artırdığı ortaya koyulmuştur. ${ }^{6}$ Özyeterliği yüksek olan öğrencilerin düşük öğrencilere k1yasla kendi performans düzeylerini doğru tahmin edebilme düzeyleri OMüiFD daha yüksektir.7 Aynı zamanda yüksek özyeterlik, öğrencilerin kendileri için yüksek hedefler belirlemelerine de sebep olmaktadır. ${ }^{8}$ Öğretmenlik mesleği dikkate alındığında akademik özyeterlik sadece öğrencilik yaşaminda değil meslek yaşamında da etkisini sürdürmeye devam eder. Öğretmenlerin mesleklerini yapabilmede sahip oldukları özyeterlik inançları

3 Salih Paşa Memişoğlu, "Nasıl Bir Öğretmen”, Ortaöğretim Yeniden Yapılanma Sempozyumu Bildiriler Kitabı (Ankara: MEB Talim Terbiye Kurulu Başkanlığı, 2006), 334338. Ali Rıza TERZİ ve Erdoğan Tezci, Necatibey Eğitim Fakültesi Öğrencilerinini Öğretmenlik Mesleğine İlişkin Tutumları, Kuram ve Uygulamada Eğitim Yönetimi, (2007) 593-614.

4 Albert Bandura, "Self-efficacy: Toward A Unifying Theory Of Behaviral Change", Psychological Review 84/2 (1994): 191-215.

5 Dale H. Schunk, "Self-Efficacy And Academic Motivaton", Educational Psychologist 26/3-4 (1991): 207-231.

6 Miraç Yılmaz v.dğr., "Akademik Özyeterlik Ölçeğinin Türkçe’ye Uyarlanması”, Hacettepe Üniversitesi Eğitim Fakültesi Dergisi 33 (2007): 253-259.

7 Therese Bouffard-Bouchard, "Influence Of Self-Efficacy Beliefs On Performance In A Cognitive Task", Journal Of Social Psychology 130 (1989): 353-363.

8 Albert Bandura, Self-Efficacy: The Exercise of Control (New York: W.H. Freeman and Company, 1997). 
iLAHIYAT FAKÜLTESi ÖĞRENCILERININ ÖĞRETMENLIK MESLEĞiNE ILIŞKIN

TUTUMLARI ILE AKADEMIK ÖZYETERLIK ALGILARI: SINOP ÖRNEĞi

sınıf içi uygulama ve sınıf dışı etkinlikleri kapsayan eğitimin planlama, uygulama ve değerlendirme aşamalarının her birinde etkisini gösterir. ${ }^{9}$

Tutum, "bir bireye atfedilen ve onun psikolojik bir obje ile ilgili düşünce, duygu ve davranışlarını düzenli bir biçimde oluşturan eğilimdir". ${ }^{10}$ Öğretmenlik mesleğine yönelik tutum dendiğinde kastedilen şey; kişinin öğretmenliğe dair olumlu ya da olumsuz duygu, düşünce ve görüşleri, mesleği benimsemesi ve öğretmen olduğunda neler yapabileceğine dair inanç ve beklentileridir. Bireyin mesleğine karşı sahip olduğu tutum mesleğini, layıkıyla yapma şeklini, mesleki yeterlik algısını ve mesleki başarısını etkilemektedir.11 Öğretmenlerin mesleklerine yönelik tutumları; mesleği sevip sevmemeye, mesleki liyakat ve mesleki başarı açısından oldukça önem taşır. ${ }^{12}$ Öğretmenlik; kişisel ve mesleki nitelikler kadar, olumlu mesleki tutum ve davranış da gerektiren bir meslektir.13 Sabır, fedakârlık ve devamlı çalışmayı gerektiren bu mesleği başarılı bir şekilde yapabilmek için mesleki sevgi ve istek gerekmektedir. ${ }^{14}$ Bunun için de, bu mesleği kendisine iş edinecek olan bireylerin öğrencilikten 215 itibaren öğretmenliğini yapacakları alanları benimsemeleri ve meslekleri hakkında olumlu tutuma sahip olmaları gerekmektedir.

Söz konusu din dersi öğretmenliği olduğunda bu mesleğe yönelik hassasiyet iyice artmaktadır. Zira kişiliğin oluştuğu çocukluk ve gençlik yıllarında değerleri de içeren din olgusunun, bir ders aracılığıyla sunul-

9 Can Nakip- Gülsen Özcan, “Öğretmen Adaylarının Öğretmenlik Mesleğine Yönelik Özyeterlik İnançları ile Öğretmenlik Mesleğine Yönelik Tutumları Arasındaki İlişki”, Mersin Üniversitesi Eğitim Fakültesi Dergisi 12/3 (2016): 783-795.

10 Çiğdem Kağıtçıaşı, Günümüzde İnsan ve İnsanlar (İstanbul: Evrim Yayınevi, 2008), 110.

11 Ergün Recepoğlu, “Öğretmen Adaylarının Yaşam Doyumları le Öğretmenlik Mesleğine Yönelik Tutumları", Hacettepe Üniversitesi Eğitim Fakültesi Dergisi 1 (2013): 311-326.

12 Mine Durmuşoğlu v.dğr., “Türk ve Azeri Öğretmen Adaylarının Öğretmenlik Mesleğine Yönelik Tutumları", Hacettepe Üniversitesi Eğitim Fakültesi Dergisi 36 (2009): 76-86.

13 Fatma Varış, Eğitimde Program Geliştirme: Teori ve Teknikler (Ankara: A.Ü. Eğitim Bilimleri Fakültesi Yayınları, 1988).

14 Yeşim Çapa- Nesrin Çil, “Öğretmen Adaylarının Öğretmenlik Mesleğine Yönelik Tutumlarının Farklı Değişkenler Açısından İncelenmesi", Hacettepe Üniversitesi Eğitim Fakültesi Dergisi 16 (2000): 13-24. 
ması pek çok avantaj ve riski beraberinde taşımaktadır. Bireysel ve toplumsal yaşamın temel yapıtaşlarından biri olan din gerçekliğinin doğru ve sağlıklı bir şekilde aktarılabilmesi ancak genel kültür, alan bilgisi ve pedagojik açıdan donanımlı, özverili, gelişime açık, mesleğini seven, uygun rol modellerle gerçekleşebilir. Son tahlilde din dersi öğretmen adaylarının akademik özyeterlik ve mesleğe yönelik tutum açısından ne durumda olduklarının tespit edilmesi gelecekte yapacakları meslek hakkında yordayıcı olabildiğinden, var olan sorunların azaltılması ve öğretmen adaylarının daha nitelikli yetişmesi hususuna katkı sunabilir.

\section{Araştırmanın Amacı}

Bu araştırmanın amacı, Sinop Üniversitesi İlahiyat Fakültesinin son sınıfında okuyan öğrencilerin öğretmenlik mesleğine yönelik tutumları ile akademik özyeterlik düzeylerini ve bu ikisi arasındaki ilişkiyi incelemektir. Ayrıca öğretmenlik mesleğine yönelik tutum ve akademik özyeterlik algısının cinsiyet, ekonomik durum, yerleşim birimi, mezun olunan ortaöğretim türü, okulu tercih nedeni, hazırlık sınıfı okuma durumu, not ortalaması, mezuniyet sonrası yapmak istenen meslek değişkenlerine göre istatistiki açıdan anlamlı bir farklılaşma oluşturup oluşturmadığını tespit etmektir.

\section{Araştırmanın Problemi}

Araştırmanın temel problemini şu sorular oluşturmaktadır: Sinop Üniversitesi İlahiyat Fakültesinde okuyan öğrencilerin öğretmenlik mesleğine yönelik tutumları nasıldır ve ne düzeydedir? Öğrencilerin akademik özyeterlik düzeyleri nedir? Bu iki değişken arasında istatistiki açıdan anlamlı bir ilişki var mıdır?

Ayrıca öğrencilerin cinsiyet, mezun oldukları ortaöğretim türü, yaşadıkları yerleşim yeri, gelir düzeyi, not ortalamaları, hazırlık okuma durumları, fakülteyi tercih etme nedeni, yapmak istedikleri meslek ile öğretmenlik mesleğine yönelik tutum ve akademik özyeterlik arasında istatistiki açıdan anlamlı bir farklılık var mıdır? 


\section{Araştırmanın Hipotezleri}

Araştırmanın hipotezleri ise şöyledir;

1. Öğrencilerin öğretmenlik mesleğine yönelik tutumları ile akademik özyeterlikleri arasında pozitif yönde ve anlamlı bir ilişki vardir.

2. Cinsiyete göre öğrencilerin öğretmenlik mesleğine yönelik tutum ve akademik özyeterlik arasında istatistiki açıdan anlamlı bir farklılaşma vardır.

3. Fakülteyi tercih nedenine göre öğrencilerin öğretmenlik mesleğine yönelik tutum ve akademik özyeterlik düzeyleri arasında istatistiki açıdan anlamlı bir farklılaşma vardır.

4. Mezun olunan ortaöğretim türü, öğretmenlik mesleğine yönelik tutum üzerinde anlamlı bir farklılık oluşturmaktadır.

5. Mezun olunan ortaöğretim türüne göre öğrencilerin akademik özyeterlik düzeyleri arasında istatistiki açıdan anlamlı bir farklılaşma yoktur.

6. Ekonomik durum, öğrencilerin öğretmenlik mesleğine yönelik tutum üzerinde anlamlı bir farklılık oluşturmamaktadır.

7. Ekonomik duruma göre öğrencilerin akademik özyeterlik düzeyleri arasında istatistiki açıdan anlamlı bir farklılaşma yoktur.

8. Yerleşim yeri ve not ortalaması öğrencilerin öğretmenlik mesleğine yönelik tutum düzeyleri üzerinde anlamlı bir farklılık oluşturmamaktadır.

9. İlde yaşayan öğrencilerin akademik özyeterlik puanları diğerlerine göre anlamlı bir şekilde farklılaşmaktadır.

10. Not ortalamasına göre öğrencilerin akademik özyeterlik düzeyleri arasında istatistiki açıdan anlamlı bir farklılaşma vardır. 
11. Hazırlık sınıfı okuyup okumama durumuna göre öğrencilerin öğretmenlik mesleğine yönelik tutum üzerinde anlamlı bir farkl1lık oluşturmamaktadır.

12. Hazırlık sınıfı okuyup okumama durumuna göre öğrencilerin akademik özyeterlik düzeyleri arasında istatistiki açıdan anlamlı bir farklilaşma yoktur.

13. Mezuniyet sonrası yapılmak istenen mesleğe göre öğrencilerin öğretmenlik mesleğine yönelik tutumları arasında istatistiki açıdan anlamlı bir farklılaşma vardır.

14. Mezuniyet sonrası yapılmak istenen mesleğe göre öğrencilerin akademik özyeterlik düzeyleri arasında istatistiki açıdan anlamlı bir farklılaşma yoktur.

\section{Araştırmanın Yöntemi}

\section{omüifD 1. Araştırma Modeli}

Araştırma, nicel araştırma yöntemlerinden ilişkisel tarama modelinde betimsel bir araştırmadır. İlişkisel araştırmalarda iki veya ikiden fazla değişken arasındaki ilişkiyi ve bu ilişkinin derecesini tespit etmek amaçlanır. ${ }^{15} \mathrm{Bu}$ çalışmada da son sınıf öğrencilerinin akademik özyeterlikleri ile öğretmenlik mesleğine yönelik tutumları ve bu ikisi arasındaki ilişki tespit edilmeye çalışıldığı için, yöntem olarak tarama modeli kullanılmıştir.

\section{Evren ve Örneklem (Araştırma Grubu)}

Araştırmanın evrenini 2018-2019 eğitim öğretim yılında Sinop Üniversitesi İlahiyat Fakültesinin son sınıfında okuyan toplam 271, örneklemini ise 209 öğrenci oluşturmaktadır. Araştırma grubunun son sınıf öğrencilerinden seçilmesinin nedeni meslek hayatına çok yaklaşmış ve öğretmenlik uygulama dersi almış olmaları sebebiyle mesleğe yönelik bilgi, tutum ve

15 Niyazi Karasar, Bilimsel Araştırma Yöntemi, 17. Baskı (Ankara: Nobel Yayıncılık, 2007), 77-81. 
ILAHIYAT FAKÜLTESi ÖĞRENCILERININ ÖĞRETMENLIK MESLEĞINE ILIŞKIN TUTUMLARI ILE AKADEMIK ÖZYETERLIK ALGILARI: SINOP ÖRNEĞi

becerilerin daha net bir şekilde ortaya çıkarılabilme olasılığıdır. Ayrıca üniversite hayatı boyunca akademik özyeterlik bakımından kendilerini daha objektif bir şekilde görebildiklerine dair inançtır.

\section{Veri Toplama Araçları}

Araştırmaya konu olan veriler; kişisel bilgi formu, "Öğretmenlik Mesleğine Yönelik Tutum Ölçeği" ve "Akademik Özyeterlik Ölçeği" ile toplanmıştır:

Kişisel Bilgi Formu: Öğrencilerin cinsiyet, ekonomik durum, yerleşim birimi, mezun olunan ortaöğretim türü, okulu tercih nedeni, hazırlık sınıfi okuma durumu, not ortalaması, mezuniyet sonrası yapmak istenen meslek gibi kişisel bilgilerini toplamak amacıyla araştırmacı tarafından hazırlanmıştır.

Öğretmenlik Mesleğine Yönelik Tutum Ölçeği (ÖMYTÖ): Tanrı̈ğen (1997) tarafından geliştirilen ölçek, 40'1 olumlu 12'si olumsuz olmak üzere toplam 52 maddeden oluşmaktadır. Ölçek beşli likert türünde hazırlanmış olup, hiç katılmıyorum (1), katılmıyorum (2), kararsızım (3), katılıyorum(4), tamamen katılıyorum (5) seklinde puanlanmaktadır. Ölçeğin olumsuz maddeleri ters olarak puanlanmaktadır. Öğrenciler ölçekten en düşük 52, en yüksek olarak 260 puan elde edebilirler. Ölçeğin orijinal güvenirlik katsayısı 0,94 iken bu araştırmadan elde edilen veriler ile ölçeğin iç tutarlık katsayısı (Cronbach's Alpha değeri) yeniden 0,94 olarak bulunmuştur.

Akademik Özyeterlik Ölçeği (AÖYÖ): Kandemir (2010) tarafından geliştirilen ölçek toplam 19 maddeden oluşmaktadır. Ölçek beşli likert türünde hazırlanmış olup, kesinlikle katılmıyorum (1), kısmen katılıyorum (2), katılıyorum (3), oldukça katılıyorum (4), kesinlikle katılıyorum (5) seklinde puanlanmaktadır. Ölçekten elde edilecek, en düşük puan 19, en yüksek puan ise 95'dir. Ölçeğin KMO katsayısı 0,93'tür. Faktör analizi sonucu ölçek üç faktörlü bir yapıya sahip olduğu görülmüştür. Birinci faktörün açıkladığı varyans \%27.73; ikinci faktörün \%14.52 ve üçüncü faktörün \%13.62“edir. Üç̧ faktörlü yapının açıkladığı toplam varyans ise 
$\% 55.89^{\circ}$ dir. Birinci faktörde yer alan 11 maddenin faktör yük değerleri 0.54 ile 0.78 arasında değişmektedir. İkinci faktörde yer alan 4 maddenin faktör yük değerleri 0.59 ile 0.78 arasındadır. Üçüncü faktörde yer alan 4 maddenin faktör yük değerleri 0.66 ile 0.78 arasında değişmektedir.

\section{Verilerin Analizi}

Örneklem grubundan toplanan veriler, IBM SPSS Statistics 20.00 programından istifade edilerek çözümlenmiştir. Yapılan analizlerde anlamlılık düzeyi 0,05 olarak alınmıştır.

Sürekli bir değişkenden elde edilen puanların normal dağılım özelliğini görebilmek için betimsel istatistikler, grafik inceleme ve normallik testi olmak üzere 3 yöntem kullanılabilir. ${ }^{16} \mathrm{Bu}$ araştırmada ölçeklerin normal dağılım gösterip göstermediğini anlamak için her 3 yönteme de bakılarak karar verilmiştir. Normallik testinde normallik varsayımı, $n>50$

220 olduğu için Kolmogorov Smirnov testiyle incelenmiştir. Nihai olarak OMüifD öğretmenlik mesleğine yönelik tutum ölçeğinin normal dağılmadığına, akademik özyeterlik ölçeğinin ise normal dağıldığına karar verilmiştir.

Bu nedenle normal dağılım gösteren akademik özyeterlik ölçeğinden elde edilen toplam puan ortalamalarının bağımsız değişkenlere göre farklılık gösterip göstermediğini belirlemek için, parametrik testlerden iki alt kategoriye ayrılan bağımsız değişkenler için "ilişkisiz örneklemler için ttesti", ikiden fazla alt kategoriye ayrılan bağımsız değişkenler için "tek faktörlü varyans analizi" testi kullanılmıştır. Normal dağılım göstermeyen öğretmenlik mesleğine yönelik tutum ölçeğinden elde edilen toplam puan ortalamalarının analizini yapmak için ise nonparametrik testlerden Kruskal Wallis H-testi ve Mann Whitney U-testi kullanılmıştır. Öğretmenlik mesleğine yönelik tutum ile akademik özyeterlik arasındaki ilişkiyi belirlemek için ise Spearmen Brown Korelasyon Katsayısı Tekniği kullanılmıştır.

16 Şener Büyüköztürk, Sosyal Bilimler İçin Veri Analizi El Kitabı (Ankara: Pegem Akade$\mathrm{mi}, 2016), 40$. 


\section{Bulgular ve Yorum}

\section{Tablo 1. Araştırmaya Katılanların Frekans Bilgileri}

Aşağıdaki tabloda araştırmaya katılan toplam 209 öğrencinin cinsiyet, yerleşim yeri, ekonomik durum, mezun olunan lise, hazırlık okuma, not ortalaması, fakülte tercih nedeni, yapmak isteği meslek değişkenlerinin sıklık bilgeleri yer almaktadır.

\begin{tabular}{|c|c|c|c|}
\hline & & $\mathbf{N}$ & $\%$ \\
\hline \multirow[t]{2}{*}{ Cinsiyet } & $\mathrm{K}_{12}$ & 121 & 57,9 \\
\hline & Erkek & 88 & 42,1 \\
\hline \multirow[t]{3}{*}{ Yerleşim yeri } & $\dot{\mathrm{Il}}$ & 77 & 36,8 \\
\hline & İlçe & 78 & 37,3 \\
\hline & Belde/köy & 54 & 25,9 \\
\hline \multirow[t]{3}{*}{ Ekonomik durum } & Düşük & 11 & 5,3 \\
\hline & Orta & 192 & 91,9 \\
\hline & Yüksek & 6 & 2,9 \\
\hline \multirow[t]{4}{*}{ Ortaöğretim türü } & Anadolu Lisesi & 25 & 12,0 \\
\hline & İmam Hatip L. & 167 & 79,9 \\
\hline & Meslek Lisesi & 9 & 4,3 \\
\hline & Diğer & 8 & 3,8 \\
\hline \multirow[t]{2}{*}{ Hazırlık okuma } & Evet & 86 & 41,1 \\
\hline & Hayır & 123 & 58,9 \\
\hline \multirow[t]{5}{*}{ Not ortalaması } & $1,5-2$ aras 1 & 13 & 6,2 \\
\hline & $2-2,5$ aras 1 & 72 & 34,4 \\
\hline & $2,5-3$ aras 1 & 86 & 41,1 \\
\hline & $3-3,5$ aras 1 & 31 & 14,8 \\
\hline & 3,5-4 aras1 & 7 & 3,3 \\
\hline \multirow{3}{*}{$\begin{array}{l}\text { Fakülte tercih } \\
\text { nedeni }\end{array}$} & Kendi tercihim & 178 & 85,2 \\
\hline & Ailemin tercihi & 20 & 9,6 \\
\hline & Diğer & 11 & 5,3 \\
\hline \multirow[t]{4}{*}{ Meslek isteği } & MEB (öğr.) & 151 & 72,2 \\
\hline & DİB (din hizm.) & 15 & 7,2 \\
\hline & Akademisyenlik & 26 & 12,4 \\
\hline & Diğer & 17 & 8,1 \\
\hline Toplam & & 209 & 100,0 \\
\hline
\end{tabular}


Tablo 2. ÖMYTÖ ve AÖTÖ'nün Betimsel İstatistikleri

\begin{tabular}{|l|c|c|c|c|}
\hline & N & Minimum & Maximum & $\overline{\mathbf{x}}$ \\
\hline Özyeterlik & 209 & 33,00 & 95,00 & 64,49 \\
\hline Tutum & 209 & 144,00 & 252,00 & 210,98 \\
\hline
\end{tabular}

Tablo 2'de de görüldüğü gibi araştırmaya katılanların ÖMYTÖ'den aldıkları en düşük puan 144, en yüksek puan 252 iken ortalamaları ise yaklaşık $\overline{x=} 211^{\prime}$ dir. Araştırmaya katılanların akademik özyeterlik ölçeğinden aldıkları en düşük puan 33, en yüksek puan 95, ortalamaları ise yaklaşık $\bar{x}=65$ puandır. Bu sonuca göre İlahiyat son sınıf öğrencilerinin genel olarak öğretmenlik mesleğine yönelik tutumları oldukça yüksek düzeyde olumlu iken, akademik özyeterlik algıları orta düzeydedir.

Araştırmaya katılanların \% 72'sinin mezuniyet sonrasında öğretmenlik yapmak istedikleri dikkate alındığında öğrencilerin tutum puanlarının yüksek çıkması normal karşılanabilir.

Öğrencilerin akademik özyeterlik algılarının çok yüksek çıkmamasının elbette pek çok nedeni olabilir. Bandura'ya göre kişilerde özyeterlik algısını etkileyen dört faktör bulunur. Bunlar; başarıya dair doğrudan yaşantılar, gözleme dayalı dolaylı yaşantılar, sözel ikna, psikolojik ve fizyolojik durum olarak sayılmaktadır. ${ }^{17}$ İlahiyat öğrencilerinin akademik özyeterliklerinin çok yüksek olmamasında bu faktörlerin hepsi ya da bazıları etkili olmuş olabilir. Öğrencilerin İlahiyat alt yapılarının eksik olması, öğrencilerin çalışma disiplini kazanamamış olmaları, sınavların zorluğu, düşük notlar, öğrencilerin birbirlerini olumsuz etkilemeleri, yeterli motivasyona sahip olmamaları gibi sebepler, onların kendilerini akademik olarak yetersiz algılamalarına neden olmuş olabilir. Öğrencilerin not ortalamasının 3 ve üzerinde olanlarının oranının sadece \% 18 ol-

17 Bandura'dan aktaran Gönül Sakız, "Başarıda Anahtar Kelime: Özyeterlik", Uludağ Üniversitesi Eğitim Fakültesi Dergisi, 26 /1 (2013): 185-210. 
ması da durumu teyit eder niteliktedir denilebilir. Özellikle tekrar eden başarısızlık öğrencilerde yılgınlık, özgüven eksikliği ve öğrenilmiş çaresizlik duyguları oluşturmakta bu durum akademik öz yeterliğe olumsuz olarak yansımaktadır denilebilir.

Tablo 3. Araştırmaya Katılanların Akademik Özyeterlikleri ile Öğretmenlik Mesleğine Yönelik Tutumları Arasındaki Spearman Brown Korelasyon Analizi

\begin{tabular}{|l|c|c|}
\hline \multirow{3}{*}{ Tutum puanı } & & Özyeterlik puanı \\
\cline { 2 - 3 } & Korelasyon & $0,26 *$ \\
\cline { 2 - 3 } & $\mathrm{p}$ & 0,000 \\
\cline { 2 - 3 } & $\mathrm{N}$ & 209 \\
\hline
\end{tabular}

Araştırmaya Katılanların Akademik Özyeterlikleri ile Öğretmenlik OMüifD Mesleğine Yönelik Tutumları arasındaki ilişkiyi görmek için yapılan Spearman Brown Korelasyon analizi sonucunda pozitif yönde ve anlamlı bir ilişki tespit edilmiştir. $(r=0,26 ; p<0,01)$. Bu sonuca göre "Öğrencilerin öğretmenlik mesleğine yönelik tutumları ile akademik özyeterlikleri arasında pozitif ve anlamlı bir ilişki vardır." şeklinde kurulan hipotez doğrulanmaktadır. İki değişken arasında pozitif bir ilişkinin olması, birinci değişkene yönelik değerlerin artması durumunda ikinci değişkenin de değerlerinin artacağ azalması durumunda ikinci değişkenin değerlerinin de azalacağı anlamına gelmektedir. ${ }^{18}$ Dolayısıyla söz konusu korelasyon katsayısının pozitif olması sonucuna göre öğrencilerin akademik özyeterlikleri artarken öğretmenlik mesleğine yönelik tutumlarının da artacağın ifade edebiliriz.

18 Büyüköztürk, Sosyal Bilimler İçin Veri Analizi El Kitabı, 32. 
Tablo 4. Araştırmaya Katılanların Mezun Oldukları Ortaöğretim Türüne Göre Öğretmenlik Mesleğine Yönelik Tutumlarının Kruskal Wallis H- Testi Sonuçları

\begin{tabular}{|l|l|l|l|l|l|}
\hline Okul Türü & N & $\mathbf{x}$ & s.d. & $\chi^{2}$ & $\mathbf{p}$ \\
\hline Anadolu Lisesi & 25 & 83,24 & & & \\
\cline { 1 - 3 } & & & & & \\
İmam Hatip L. & 167 & 105,73 & \multirow{2}{*}{2} & 6,134 & 0,04 \\
\hline Meslek Lisesi & 17 & 129,85 & & & \\
\hline Toplam & $\mathbf{2 0 9}$ & & & & \\
\hline
\end{tabular}

Yapılan Kruskal Wallis H- testi testi sonucuna göre öğretmenlik mesleğine yönelik tutum ile mezun olunan ortaöğretim türü arasında istatistiki açıdan anlamlı bir ilişki olduğu ortaya çıkmıştır. ( $p=0,04 ; p<0,05)$. Anlamlı farklılaşmanın hangi gruplar arasında olduğunu görmek için yaptığımız Mann Witneyy testine göre Anadolu Lisesi ile Meslek Lisesi öğrencilerinin puan ortalamaları arasında anlamlı bir fark olduğu tespit edilmiştir. Yani Meslek Lisesi mezunlarının öğretmenlik mesleğine yönelik tutumları (129,85 puan) ile Anadolu Lisesi mezunlarının öğretmenlik mesleğine yönelik tutumları (83,24 puan) arasında manidar bir farklılaşma bulunmaktadır. Bu sonuca göre "Mezun olunan ortaöğretim türü, öğretmenlik mesleğine yönelik tutum üzerinde anlamlı bir farklılık oluşturmaktadır." şeklindeki hipotez doğrulanmıştır.

$\mathrm{Bu}$ analiz testinde dikkat çeken unsur İmam Hatip Lisesi öğrencilerinin öğretmenlik mesleğine yönelik tutum puan ortalamalarının (105,73 puan) Meslek Lisesi öğrencilerinden daha düşük çıkmış olmasıdır. $\mathrm{Bu}$ sonuçta Meslek Lisesi öğrencilerinin sayısının az olmasının etkisinin olduğu düşünülmektedir. Ya da Meslek Lisesi mezunu öğrencilerin bu bölümü tercih ettiklerine göre din dersi öğretmenliği yapma konusunda idealist bir yaklaşıma sahip oldukları da düşünülebilir. Bizim araştırmamızın aksine Çetin (2017) tarafından yapılan bir başka araştırmada İmam 
Hatip Lisesi öğrencileri lehine öğretmenlik mesleğine yönelik tutum puanları anlamlı bir şekilde farklılaşmaktadır. ${ }^{19}$

\begin{tabular}{|c|c|c|c|c|c|}
\hline Meslek & $\mathbf{N}$ & $\bar{x}$ & Sd. & $\overline{\chi^{2}}$ & p \\
\hline MEB'de öğretmenlik & 151 & 120,28 & \multirow{5}{*}{3} & \multirow{5}{*}{40,54} & \multirow{5}{*}{0,000} \\
\hline DİB'de din hizmetleri & 15 & 53,17 & & & \\
\hline Akademisyenlik & 26 & 86,10 & & & \\
\hline$\overline{\text { Diğer }}$ & 17 & 43,94 & & & \\
\hline Toplam & 209 & & & & \\
\hline
\end{tabular}

Yapılan Kruskal Wallis H- testi sonucuna göre öğretmenlik mesleğine yönelik tutum ile mezuniyet sonrası yapılmak istenen meslek arasında istatistiki açıdan anlamlı bir ilişki vardır. $(\mathrm{p}<0.01)$ Bu sonuca göre "Mezuniyet sonrası yapılmak istenen mesleğe göre öğrencilerin öğretmenlik mesleğine yönelik tutum arasında istatistiki açıdan anlamlı bir farklılaşma vardır." şeklindeki hipotez doğrulanmıştır. Söz konusu farklılaşmanın hangi gruplarda ortaya çıktığını görmek için yapılan Mann Witneyy testi sonuca göre MEB'de öğretmenlik ile DİB'de din hizmetleri arasında $\mathrm{p}<0,001$ düzeyinde; MEB'de öğretmenlik ile akademisyenlik arasında $\mathrm{p}<0,01$ düzeyinde; MEB'de öğretmenlik ile diğer seçeneği arasında $\mathrm{p}<0,001$ düzeyinde; akademisyenlik ile diğer seçeneği arasında $p<0,01$ düzeyinde anlamlı bir farklılaşma bulunmaktadır. Bu sonuca göre MEB'de öğretmenlik yapmak isteyenlerin öğretmenlik mesleğine yönelik tutum ortalamaları ile diğer meslekleri seçmek isteyen öğrencilerin öğretmenlik mesleğine yönelik tutum ortalamaları arasında önemli fark

19 Özer Çetin, “İslami İlimler/Illahiyat Fakültesi Öğrencilerinin Öğretmenlik Mesleğine Yönelik Tutumlarının İncelenmesi (Uşak Üniversitesi Örneği)", Hitit Üniversitesi İlahiyat Fakültesi Dergisi 16/32 (2017): 411-432. 
olduğu ortaya çıkmıştır. Bu durum öğretmen olmak isteyen öğrencilerin öğretmenlik mesleğine yönelik olumlu tutum geliştirmesi ve mesleği sevmesinin doğal ve beklenilen bir sonuç olduğunu ortaya koymaktadır. Öğrencilerin DİB'de görev yapmak isteyenlerin sayısının çok az olması dikkat çekmektedir.

Tablo 6. Fakülteyi Tercih Nedeni İle Öğretmenlik Mesleğine Yönelik Tutum Arasında Kruskal Wallis Testi Sonuçları

\begin{tabular}{|l|c|c|c|c|c|}
\hline & $\mathbf{N}$ & $\mathbf{x}^{-}$ & s.d. & $\chi^{2}$ & $\mathbf{p}$ \\
& & & & & \\
\hline Kendi tercihim & 178 & 111,06 & & & \\
\cline { 1 - 3 } & & & & & \\
Ailemin tercihi & 20 & 74,50 & \multirow{2}{*}{2,32} & 0,002 \\
\hline Diğer & 11 & 62,45 & & & \\
\hline Toplam & $\mathbf{2 0 9}$ & & & & \\
\hline
\end{tabular}

Yapılan Kruskal Wallis H- testi sonucuna göre öğretmenlik mesleğine yönelik tutum ile fakülteyi tercih nedeni arasında istatistiki açıdan anlamlı bir ilişki vardır. $(\mathrm{p}<0,01) \mathrm{Bu}$ farklılaşmanın hangi gruplar arasında olduğunu tespit etmek için yapılan Mann Witneyy testi sonucuna göre fakülteyi tercih nedeni olarak kendi tercihim diyen öğrencilerin öğretmenlik mesleğine yönelik tutum puan ortalamaları ile ailemin tercihi diyenler arasında $\mathrm{p}<0,01$ düzeyinde anlamlı bir fark tespit edilmiştir. $\mathrm{O}$ halde "Fakülteyi tercih nedinine göre öğrencilerin öğretmenlik mesleğine yönelik tutum puan ortalaması arasında istatistiki açıdan anlamlı bir farklılaşma vardır." şeklindeki hipotez doğrulanmıştır. Çetin (2017) tarafından yapılan araştırma da okuduğu fakülteye kendi isteğiyle gelen öğrencilerin diğerlerine oranla öğretmenlik mesleğine yönelik tutum puanları anlamlı bir şekilde farklılaşmaktadır. Yine Gürbüz ve Kışoğlu (2007)'nun 
yaptığ1 çalışmalar da bu bulguyu destekler nitelikte sonuçlar vermiştir. ${ }^{20}$ $\mathrm{Bu}$ sonuç okudukları bölüme kendi istekleriyle gelen öğrencilerin mezuniyet sonrası yapacakları öğretmenlik mesleğine yönelik olumlu olarak yansıyacağı şeklinde yorumlanabilir.

Tablo 7. Not Ortalaması ve Yerleşim Yeri İle Öğretmenlik Mesleğine Yönelik Tutum Arasında Kruskal Wallis H- Testi Sonuçları

\begin{tabular}{|l|l|l|l|l|l|l|}
\hline & & $\mathbf{N}$ & $\mathbf{x}$ & s.d. & $\chi^{2}$ & $\mathbf{p}$ \\
\hline Not ort. & $1,50-2,00$ & 13 & 107,08 & & & \\
& $2,01-2,50$ & 72 & 96,91 & & & \\
& $2,51-3,00$ & 86 & 110,09 & \multirow{2}{*}{3} & 2,014 & 0,57 \\
\cline { 2 - 4 } & $3,01-4,00$ & 38 & 108,09 & & & \\
\cline { 2 - 4 } $\begin{array}{l}\text { Yaşadığ1 } \\
\text { yer }\end{array}$ & İl & 77 & 106,19 & & & \\
\cline { 2 - 4 } & İlçe & 78 & 111,32 & \multirow{2}{*}{2} & 2,616 & 0,27 \\
\cline { 2 - 4 } & Belde/Köy & 54 & 94,17 & & & \\
\hline
\end{tabular}

Tablo 7'de de görüldüğü gibi yapılan Kruskal Wallis testi sonucuna göre öğretmenlik mesleğine yönelik tutum ile öğrencilerin not ortalamaları ve yaşadıkları yerleşim yeri arasında istatistiki açıdan anlamlı bir ilişki bulunmamaktadır. ( $p>0,05)$ Bu sonuca göre "Yerleşim yeri, öğretmenlik mesleğine yönelik tutum üzerinde anlamlı bir farklılık oluşturmamaktadır." ve "Not ortalaması öğretmenlik mesleğine yönelik tutum üzerinde anlamlı bir farklılık oluşturmamaktadır." şeklindeki hipotezler doğrulanmıştır. Not ortalaması 1,50-2,00 olan öğrencilerin öğretmenlik meslekine yönelik tutum puanları $\bar{x}=107,08 ; 2,01-2,50$ ortalamaya sahip öğrencilerin öğretmenlik meslekine yönelik tutum puanları $\bar{x}=96,91 ; 2,51$ -

20 Hasan Gürbüz - Mustafa Kışoğlu, "Tezsiz Yüksek Lisans Programına Devam Eden FenEdebiyat ve Eğitim Fakültesi Öğrencilerinin Öğretmenlik Mesleğine Yönelik Tutumları (Atatürk Üniversitesi Örneği)", Erzincan Eğitim Fakültesi Dergisi 9/2 (2007): 71-83. 
3,00 olan öğrencilerin öğretmenlik meslekine yönelik tutum puanları $\bar{x}=$ 110,09; 3,01-4,00 ortalamaya sahip öğrencilerin öğretmenlik mesleğine yönelik tutum puanları $\bar{x}=108,09^{\prime}$ dur.

Öğrencilerin not ortalamalarına göre öğretmenlik mesleğine yönelik tutumları arasında anlamlı düzeyde fark olmamasının nedeni ise öğrencilerin düşük not ile mesleği sevme arasında bir ilişki görmemelerinden kaynaklı olabilir. Daha açık bir ifadeyle öğrenciler, akademik başarısızlığın mesleğe yönelik olumsuz duygular beslenmesini gerektirmeyeceği yönünde inanç benimsemişlerdir diyebiliriz. Alanda yapılan araştırmalara baktığımızda bu bulguyu destekler nitelikte çalışmaların olduğunu görmekteyiz.21 Bununla birlikte Abbasoğlu ve Öncü (2013) tarafından yapılan bir başka araştırmada ise öğretmen adaylarının akademik başarıları ile öğretmenlik mesleğine yönelik tutumları arasında anlamlı bir ilişki bulunmuştur. ${ }^{22}$

Tablo 8. Cinsiyet, Ekonomik Durum, Hazırlık Okuma İle Öğretmenlik Mesleğine Yönelik Tutum Arasındaki Mann Withney U- Testi Sonuçları

\begin{tabular}{|l|l|l|l|l|l|}
\hline \multicolumn{2}{|c|}{} & N & $\bar{x}$ & U & $\mathrm{p}$ \\
\hline \multirow{2}{*}{$\begin{array}{l}\text { Ekonomik } \\
\text { durum }\end{array}$} & Düşük & 11 & 121,91 & \multirow{2}{*}{903,00} & 0,341 \\
\cline { 2 - 5 } & Orta/yüksek & 198 & 104,06 & & \\
\hline \multirow{2}{*}{ Cinsiyet } & Kız & 121 & 110,75 & \multirow{2}{*}{4628,00} & 0,107 \\
\cline { 2 - 4 } & Erkek & 88 & 97,09 & & \\
\hline Hazırlık & Evet & 86 & 101,16 & 4959,00 & 0,443 \\
\hline
\end{tabular}

21 Hasan Özder v.dğr., “Öğretmen Adaylarının Öğretmenlik Mesleğine Yönelik Tutumlarının Çeşitli Değişkenler Açısından İncelenmesi", Kuram ve Uygulamada Eğitim Yönetimi 16/2 (2010): 253-275, Nakip - Özcan, “Öğretmen Adaylarının Öğretmenlik Mesleğine Yönelik Özyeterlik İnançları ile Öğretmenlik Mesleğine Yönelik Tutumları Arasındaki İlişki", 783-795.

22 Eda Abbasoğlu - Erman Öncü, "Beden Eğitimi Öğretmen Adaylarının Benlik Saygıları ve Öğretmenlik Mesleğine Yönelik Tutumları", Ahi Evran Üniversitesi Kırşehir Eğitim Fakültesi Dergisi 14/2 (2013): 407-425. 
ILAHIYAT FAKÜLTESI ÖĞRENCILERININ ÖĞRETMENLIK MESLEĞINE ILIŞKIN TUTUMLARI ILE AKADEMIK ÖZYETERLIK ALGILARI: SINOP ÖRNEĞi

\begin{tabular}{|l|l|l|l|l|l|}
\hline okuma & Hayır & 123 & 107,68 & & \\
\hline
\end{tabular}

Tablo 8'de görüldügü gibi yapılan Mann Withney U testi sonucuna göre öğretmenlik mesleğine yönelik tutum ile cinsiyet, ekonomik durum ve hazırlık okuma değişkenleri arasında istatistiki açıdan anlamlı bir ilişki bulunmamaktadır. "Ekonomik durum, öğretmenlik mesleğine yönelik tutum üzerinde anlamlı bir farklılık oluşturmamaktadır." ve "Hazırlık sınıfı okuyup okumama durumu öğrencilerin öğretmenlik mesleğine yönelik tutumu üzerinde anlamlı bir farklılık oluşturmamaktadır." şeklindeki hipotezler doğrulanmıştır. "Cinsiyete göre öğrencilerin öğretmenlik mesleğine yönelik tutum ortalamaları arasında istatistiki açıdan anlamlı bir fark vardır." şeklindeki hipotez desteklenmemektedir. Yani öğrencilerin ileride yapacakları öğretmenlik mesleğine yönelik tutumlarını cinsiyet etkilememektedir. Hem kız hem erkek öğrenciler öğretmenlik mesleğine yönelik yüksek düzeyde olumlu tutum içindedirler. Her ne kadar istatistiki açıdan anlamlı bir farklılaşma olmasa da İlahiyat Fakülte229 si öğrencilerinde kız öğrencilerin öğretmenlik mesleğine yönelik tutum puanlarının yüksek çıkması istendik ve beklendik bir durumdur. Bu sonuç, özellikle kadının çalışmasına sıcak bakmayan geleneksel anlayışın kırıldığ 1 ve kız öğrencilerin de kendilerini çalışma hayatına öğrencilikten itibaren bilinçli ve istekli bir şekilde hazırladıkları şeklinde yorumlanabilir. Ayrıca toplumsal açıdan cinsiyet ayrımının yavaş yavaş ortadan kalktığına yönelik bir işaret olarak da görülebilir. Aktaş tarafından yapılan bir araştırmada da cinsiyet ve ekonomik durum ile öğretmenlik mesleğine yönelik tutum arasında anlamlı bir farklılaşmanın olmadığı tespit edilmiştir. ${ }^{23}$ Bununla birlikte bazı araştırmalar kız öğrenciler lehine anlamlı farklılaşmanın olduğunu ortaya koymuşlardır. ${ }^{24}$ Çetin tarafından İlahiyat

23 Hamza Aktaş, “Akademik Güdülenme İle Akademik Özyeterlik Arasındak İlişki: İlahiyat Fakültesi Öğrencileri Üzerine Ampirik Bir Araştırma", İnsan ve Toplum Bilimleri Dergisi 6/3 (2017): 1376-1398.

24 Burhan Çapri - Öner Çelikkaleli, "Öğretmen Adaylarının Öğretmenliğe İlişkin Tutum ve Mesleki Yeterlik İnançlarının Cinsiyet, Program ve Fakültelerine Göre İncelenmesi", İnönü Üniversitesi Eğitim Fakültesi Dergisi 9/15 (2008): 33-53. 
öğrencileri üzerine yapılan bir araştırmada da kız öğrenciler lehine öğretmenlik mesleğine yönelik tutum puanları anlamlı bir şekilde farkl1laşmaktadır. ${ }^{25}$ Bazı araştırma bulguları ise erkek öğrenciler lehine anlamlı bir farklılaşmanın olduğunu ortaya koymaktadır. ${ }^{26}$ Dolayısıyla cinsiyet faktörünün tek başına tutum üzerinde belirleyici olmadığını ifade edebiliriz.

Tablo 9. Cinsiyet, Ekonomik Durum ve Hazırlık Okuma Değişkenlerine Göre Öğrencilerin Akademik Özyeterlik Düzeyleri Arasında Yapılan t-Testi Sonuçları

\begin{tabular}{|c|c|c|c|c|c|c|}
\hline & & $\mathrm{N}$ & $\bar{x}$ & s.d & $\mathrm{t}$ & $\mathrm{p}$ \\
\hline \multirow[t]{2}{*}{ Cinsiyet } & $\mathrm{K}_{1 \mathrm{z}}$ & 121 & 63,72 & \multirow{2}{*}{207} & \multirow{2}{*}{$-0,84$} & \multirow{2}{*}{0,39} \\
\hline & Erkek & 88 & 65,54 & & & \\
\hline \multirow[t]{2}{*}{ Hazırlık } & Evet & 86 & 66,72 & \multirow{2}{*}{207} & \multirow{2}{*}{1,77} & \multirow{2}{*}{0,07} \\
\hline & Hayır & 123 & 62,93 & & & \\
\hline \multirow{2}{*}{$\begin{array}{l}\text { Ekonomik } \\
\text { durum }\end{array}$} & Düşük & 11 & 64,90 & \multirow{2}{*}{207} & \multirow{2}{*}{0,93} & \multirow{2}{*}{0,926} \\
\hline & Orta- Yük. & 198 & 64,46 & & & \\
\hline
\end{tabular}

Yapılan t- testi sonucuna göre öğrencilerin özyeterlik düzeyleri ile cinsiyet, ekonomik gelir, hazırlık okuma arasında istatistiksel bakımdan anlamlı bir ilişki bulunamamıştır. Bu sonuca göre "Hazırlık sınıfı okuyup okumama durumuna göre öğrencilerin akademik özyeterlik düzeyleri arasında istatistiki açıdan anlamlı bir fark yoktur." ve "Ekonomik duruma göre öğrencilerin akademik özyeterlik düzeyleri arasında istatistiki açıdan anlamlı bir fark yoktur." şeklindeki hipotezler doğrulanırken; “Cinsiyete göre öğrencilerin akademik özyeterlik düzeyleri arasında ista-

25 Çetin, “İslami İlimler/İlahiyat Fakültesi Öğrencilerinin Öğretmenlik Mesleğine Yönelik Tutumlarının İncelenmesi (Uşak Üniversitesi Örneği)", 411-432.

26 Şuheda Özben, “Tezsiz Yüksek Lisans Öğrencilerinin Öğretmenlik Mesleğine İlişkin Tutumlarının İncelenmesi", D.E.Ü. Buca Eğitim Fakültesi Dergisi 1 (2010): 37-43. 
tistiki açıdan anlamlı bir fark vardır." şeklindeki hipotezimiz doğrulanmamıştır.

Ataerkil toplumlarda erkek öğrencilerin kızlara oranla akademik özyeterlik açısından kendilerini daha yüksek görmeleri daha olası bir durumdur. ${ }^{27} \mathrm{Bu}$ araştırmada da çok küçük bir farkla da olsa benzer sonuç çıkmıştır. Fakat istatistiki açıdan anlamlı bir fark oluşturacak düzeyde değildir. Bu durum toplumsal cinsiyet rollerinde önemli değişikliklerin olduğunu ve kız öğrencilerin de artık kendilerini erkekler gibi toplum içerisinde üstlendikleri rollerde başarılı ve yeterli hissettiklerini göstermektedir, şeklinde yorumlanabilir.

Tablo 10. Akademik Özyeterlik İle Yerleşim Yeri, Not Ortalaması, Mezun Olunan Ortaöğretim Türü, Fakülteyi Tercih Nedeni, Yapılmak İstenen Meslek Değişkenleri Arasındaki İlişki İle İlgili Yapılan ANOVA Testi Sonuçları

\begin{tabular}{|c|c|c|c|c|c|c|}
\hline & & $\mathrm{N}$ & $\bar{x}$ & s.d. & $\mathrm{f}$ & $\mathrm{p}$ \\
\hline \multirow{3}{*}{$\begin{array}{l}\text { Yerleşim } \\
\text { birimi }\end{array}$} & İl & 77 & 66,22 & \multirow{3}{*}{2} & \multirow{3}{*}{0,78} & \multirow{3}{*}{0,45} \\
\hline & İçe & 78 & 63,34 & & & \\
\hline & Belde/Köy & 54 & 63,68 & & & \\
\hline \multirow{4}{*}{$\begin{array}{l}\text { Not ortala- } \\
\text { masi }\end{array}$} & $1,5-2,00$ & 13 & 58,07 & \multirow{4}{*}{3} & \multirow{4}{*}{1,21} & \multirow{4}{*}{0,30} \\
\hline & $2,01-2,50$ & 72 & 63,73 & & & \\
\hline & $2,51-3,00$ & 86 & 66,25 & & & \\
\hline & $3,01-4,00$ & 38 & 64,13 & & & \\
\hline \multirow{2}{*}{$\begin{array}{l}\text { Ortaöğretim } \\
\text { türü }\end{array}$} & Anadolu Lisesi & 25 & 59,84 & \multirow{2}{*}{2} & \multirow{2}{*}{1,77} & \multirow{2}{*}{0,17} \\
\hline & İmam Hatip L. & 167 & 64,78 & & & \\
\hline
\end{tabular}

27 Sinem Evin Akbay - Cem Ali Gizir, “Cinsiyete Göre Üniversite Öğrencilerinde Aademik Erteleme Davranışı: Akademik Güdülenme, Akademik Özyeterlik ve Akademik Yükleme Stillerinin Rolü", Mersin Üniversitesi Eğitim Fakültesi Dergisi 6/1 (2010): 60-78. 


\begin{tabular}{|c|c|c|c|c|c|c|}
\hline & $\begin{array}{l}\text { Meslek lisesi } \\
\text { vb. }\end{array}$ & 17 & 68,47 & & & \\
\hline \multirow{3}{*}{$\begin{array}{l}\text { Fakülte ter- } \\
\text { cihi }\end{array}$} & Kendi tercihim & 178 & 64,97 & \multirow{3}{*}{2} & \multirow{3}{*}{0,58} & \multirow{3}{*}{0,55} \\
\hline & Ailemin tercihi & 20 & 61,70 & & & \\
\hline & Diğer & 11 & 61,81 & & & \\
\hline \multirow[t]{4}{*}{ Meslek } & MEB'de öğr. & 151 & 64,52 & \multirow{4}{*}{3} & \multirow{4}{*}{0,43} & \multirow{4}{*}{0,72} \\
\hline & DİB'de din hiz. & 15 & 60,66 & & & \\
\hline & Akademis. & 26 & 66,30 & & & \\
\hline & Diğger & 17 & 64,76 & & & \\
\hline
\end{tabular}

Yapılan Anova testi sonucuna göre özyeterlik puanı ile yerleşim yeri, mezun olunan ortaöğretim türü, fakülteyi tercih nedeni, mezuniyet sonrası yapılmak istenen meslek, okul başarı puanı arasında istatistiki açıdan anlamlı bir ilişki tespit edilememiştir. $(\mathrm{p}>0,05)$ Bu neticeye göre "Hazırlık sınıfı okuyup okumama durumuna göre öğrencilerin akademik özyeterlik düzeyleri arasında istatsitiki açıdan anlamlı bir fark yoktur." ve "Mezun olunan ortaöğretim türüne göre öğrencilerin akademik özyeterlik düzeyleri arasında istatistiki açıdan anlamlı bir fark yoktur." şeklindeki hipotezler doğrulanmıştır. Fakat "Not ortalamasına göre öğrencilerin akademik özyeterlik düzeyleri arasında istatistiki açıdan anlamlı bir fark vardır." "İlde yaşayan öğrencilerin akademik özyeterlik puanları ile diğer yerleşim yerlerinde yaşayan öğrencilerin puanları arasında anlamlı bir fark vardır." "Fakülteyi tercih nedenine göre öğrencilerin akademik özyeterlik düzeyleri arasında istatistiki açıdan anlamlı bir fark vardır." şeklindeki hipotezler doğrulanmazken, "Mezuniyet sonrası yapılmak istenen mesleğe göre öğrencilerin akademik özyeterlik düzeyleri arasında istatistiki açıdan anlamlı bir farklılaşma yoktur. şeklindeki hipotez doğrulanmıştır. Özellikle not ortalaması ile akademik özyeterlik arasında bir ilişkinin olmaması dikkat çekicidir. Oysaki çoğunlukla akademik özyeterlik 
algıSı yüksek olan üniversite öğrencilerinde daha iyi akademik başarıları beklenmektedir. ${ }^{28}$ Not ortalaması 1,50-2,00 olan öğrencilerin akademik özyeterlik $\bar{x}=58,07 ; 2,01-2,50$ ortalamaya sahip öğrencilerin akademik özyeterlik $\bar{x}=63,73 ; 2,51-3,00$ olan öğrencilerin $\bar{x}=66,25 ; 3,01-4,00$ ortalamaya sahip akademik özyeterlik $\bar{x}=64,13^{\prime}$ dür. (Alınabilecek en yüksek tutum puanı 95'dir). Bu sonuç kişisel algılardan oluşan öz yeterliğin öğrenciler nezdinde sadece not ortalamasına göre belirlenemeyeceği şeklindeki inancı yansitıyor olabilir. Bununla birlikte en düşük akademik özyeterlik puanının, not ortalaması en düşük olan öğrencilerde ortaya çıktığ1nı dikkate aldığımızda istatistiki açıdan anlamlı fark oluşturmasa da özyeterlik ile akademik özyeterlik arasında bir ilişki olduğunu ifade edebiliriz. Bu araştırma sonucuyla paralel özellik gösteren araştırmalar bulunmaktadır. ${ }^{29}$ Bununla birlikte akademik özyeterlik ile akademik başarı arasında anlamlı bir ilişki olduğunu ortaya koyan çok sayıda araştırma bulunmaktadır. ${ }^{30}$

\section{Sonuç}

İlahiyat Fakültesi son sınıf öğrencilerin öğretmenlik mesleğine yönelik tutumu ile akademik özyeterlikleri arasındaki ilişkiyi inceleyen bu araştırma sonucuna göre araştırmaya katılan öğrencilerin öğretmenlik mesleğine yönelik tutumları oldukça yüksek düzeyde olumlu bulunmuştur. ( $\overline{x=211) ~ O ̈ g ̆ r e n c i l e r i n ~ a k a d e m i k ~ o ̈ z y e t e r l i k ~ p u a n ~ o r t a l a m a l a r ı ~ i s e ~ o r t a ~}$ düzeyde çıkmıştır. ( $\overline{x=} 65)$ Öğretmenlik mesleğine yönelik tutum ile akademik özyeterlik arasında pozitif yönde ve anlamlı bir ilişki tespit edilmiştir.(r=0,26; $\mathrm{p}<0,01)$.

28 Chemers, Hu ve Garcia, 2001'den akt. Aktaş, “Akademik Güdülenme İle Akademik Özyeterlik Arasındak İlişki: İlahiyat Fakültesi Öğrencileri Üzerine Ampirik Bir Araştırma", 1376-1398.

29 Ethem Yeşilyurt, "Öğretmen Adaylarının Öğretmen Özyeterlik Algıları", Elektronik Sosyal Bilimler Dergisi 12/45 (2013): 88-104, Nakip Özcan, “Öğretmen Adaylarının Öğretmenlik Mesleğine Yönelik Özyeterlik İnançları ile Öğretmenlik Mesleğine Yönelik Tutumları Arasındaki İlişki", 783-795.

30 Sakız, "Başarıda Anahtar Kelime: Özyeterlik", 185-209. 
Yapılan Kruskal Wallis Testi ve Mann Withney U- Testi sonuçlarına göre; Öğretmenlik mesleğine yönelik tutum ile mezun olunan ortaöğretim türü arasında istatistiki açıdan anlamlı bir ilişki vardır. ( $p=0,04$; $p<0,05)$. Yine öğretmenlik mesleğine yönelik tutum ile mezuniyet sonrası yapılmak istenen meslek arasında istatistiki açıdan anlamlı bir ilişki vardır. ( $p=0,00 ; p<0.01)$ Öğretmenlik mesleğine yönelik tutum ile fakülteyi tercih nedeni arasında istatistiki açıdan anlamlı bir ilişki vardır. ( $p=, 002$; $p<0,05)$. Öğretmenlik mesleğine yönelik tutum ile öğrencilerin akademik başarıları, yaşadıkları yerleşim yeri, cinsiyet, ekonomik durum ve hazırlık okuma değişkenleri arasında istatistiki açıdan anlamlı bir ilişki bulunmamaktadir.

Yapılan t testi ve ANOVA test sonuçlarına göre akademik özyeterlik puanı ile cinsiyet, ekonomik gelir, yerleşim yeri, mezun olunan ortaöğretim türü, hazırlık okuma, fakülteyi tercih nedeni, yapılmak istenen mesOMüifD namamıştır.

\section{Bu sonuçlara göre;}

“Öğrencilerin öğretmenlik mesleğine yönelik tutumları ile akademik özyeterlikleri arasında pozitif yönde ve anlamlı bir ilişki vardır." Şeklindeki 1. hipotez doğrulanmıştır.

“Cinsiyete göre öğrencilerin öğretmenlik mesleğine yönelik tutum ve akademik özyeterlik düzeyleri arasında istatistiki açıdan anlamlı bir farklılaşma vardır." Şeklindeki 2. hipotez doğrulanmamıştır.

“Fakülteyi tercih nedenine göre öğrencilerin öğretmenlik mesleğine yönelik tutum ve akademik özyeterlik düzeyleri arasında istatistiki açıdan anlamlı bir farklılaşma vardır." Şeklindeki 3. hipotezin ilk kısmı doğrulanmiştır.

"Mezun olunan ortaöğretim türü, öğrencilerin öğretmenlik mesleğine yönelik tutumları üzerinde anlamlı bir farklılık oluşturmaktadır." Şeklindeki 4. hipotez doğrulanmamıştır. 
"Mezun olunan ortaöğretim türüne göre öğrencilerin akademik özyeterlik düzeyleri arasında istatistiki açıdan anlamlı bir farklılaşma yoktur." Şeklindeki 5. hipotez doğrulanmıştır.

“Ekonomik durum, öğrencilerin öğretmenlik mesleğine yönelik tutumları üzerinde anlamlı bir farklılık oluşturmamaktadır." Şeklindeki 6. hipotez doğrulanmıştır.

“Ekonomik duruma göre öğrencilerin akademik özyeterlik düzeyleri arasında istatistiki açıdan anlamlı bir farklılaşma yoktur." Şeklindeki 7. hipotez doğrulanmıştır.

“Yerleşim yeri ve not ortalaması, öğrencilerin öğretmenlik mesleğine yönelik tutum düzeyleri üzerinde anlamlı bir farklılık oluşturmamaktadır." Şeklindeki 8. hipotez doğrulanmıştır.

"İlde yaşayan öğrencilerin akademik özyeterlik puanları diğerlerine göre anlamlı bir şekilde farklılaşmaktadır." Şeklindeki 9. hipotez doğrulanmamıştır.

"Not ortalamasına göre öğrencilerin akademik özyeterlik düzeyleri arasında istatistiki açıdan anlamlı bir farklılaşma vardır." Şeklindeki 10. hipotez doğrulanmamıştır.

“Hazırlık sınıfı okuyup okumama durumu, öğrencilerin öğretmenlik mesleğine yönelik tutum üzerinde anlamlı bir farklılık oluşturmamaktadır." Şeklindeki 11. hipotez doğrulanmıştır.

“Hazırlık sınıfı okuyup okumama durumuna göre öğrencilerin akademik özyeterlik düzeyleri arasında istatistiki açıdan anlamlı bir farklılaşma yoktur." Şeklindeki 12. hipotez doğrulanmıştır.

“Mezuniyet sonrası yapılmak istenen mesleğe göre öğrencilerin öğretmenlik mesleğine yönelik tutumları arasında istatistiki açıdan anlamlı bir farklılaşma vardır." Şeklindeki 13. hipotez doğrulanmıştır. 
“Mezuniyet sonrası yapılmak istenen mesleğe göre öğrencilerin akademik özyeterlik düzeyleri arasında istatistiki açıdan anlamlı bir farklılaşma yoktur." Şeklindeki14. hipotez doğrulanmıştır.

Öneriler

\section{Araştırmada ortaya çıkan bu sonuçların ardından şu önerilerde bulunu- labilir:}

1. Bu araştırmada öğrencilerin akademik özyeterlikleri ile diğer değişkenler arasında anlamlı bir ilişki bulunamamıştır. O halde öğrencilerin akademik özyeterliklerinin orta düzeyde olmasına ya da çok yüksek olmamasına etki eden daha başka faktörler bulunmaktadır. Öğrencilerin akademik özyeterliklerin hangi unsurlar tarafından etkilendiğinin tespit edilebilmesi için farklı İlahiyat fakültelerinde farklı örneklem sayısıyla ve farklı değişkenler açısından konu tekrar araştırılabilir. Daha detaylı so-

236 nuçlar ortaya çıkarabilmek için özellikle nitel çalışmalar yapılabilir.

OMüiFD 2. Öğrencilerin orta düzeyde olan akademik özyeterliklerini artırmaya yönelik bireysel gelişim ve rehberlik hizmetleri yapılabilir.

3. Öğrencilerin doğrudan yaşantılarındaki başarılarının artması için birinci sınıftan itibaren kolaydan zora, basitten karmaşığa doğru tedrici eğitime önem verilerek, öğrencilerde öğrenilmiş çaresizlik psikolojisi oluşturulmamalıdır.

4. Öğrencilerin akademik özyeterlik algılarının artırılması için başarabilecekleri seviyede proje ödevleri ve sunumlar hazırlatılabilir.

5. Dolaylı yaşantılardaki olumsuz örnekleri azaltabilmek için başarılı ve akademik özyeterlikleri yüksek İlahiyat mezunları ile buluşmalarını sağlayan etkinlikler düzenlenebilir.

6. Öğrencilere psikolojik ve fizyolojik durumlarının iyileştirilmesine yönelik sözel ikna araçlarına başvurulabilir. Bu bağlamda öğretim üyelerinin öğrenme ortamlarında öğrencilere olumlu geri dönütler vermesi, öğrencilerin başarı ve öğrenmeye dair sorunlarını çözme konusunda rehberlik yapması etkili olabilir. 
iLAHIYAT FAKÜLTESi ÖĞRENCILERININ ÖĞRETMENLIK MESLEĞiNE ILIŞKIN

TUTUMLARI ILE AKADEMIK ÖZYETERLIK ALGILARI: SINOP ÖRNEĞi

7. Öğretmenlik mesleğine yönelik tutumun olumlu ve yüksek olması için öğretmen yetiştiren fakültelerin eğitim imkânlarının iyileştirilmesi gerekir.

8. Eğitim fakültesine öğrenci alımında öğrencilerin mesleki sevgi ve özveri gibi öğretmenlik mesleğine uygun özelliklerinin tespit edildiği bir mülakat sinavı yapılabilir.

9. Öğrencilere üniversite tercihleri esnasında aileler ve rehberlik öğretmenleri tarafından doğru rehberlik yapılarak, öğretmenliği sevmeyen öğrencilerin eğitim fakültesi tercihi yapmaması sağlanabilir.

\section{Kaynakça}

Abbasoğlu, Eda - Öncü, Erman. "Beden Eğitimi Öğretmen Adaylarının Benlik Saygıları ve Öğretmenlik Mesleğine Yönelik Tutumları". Ahi Evran Üniversitesi Kirşehir Eğitim Fakültesi Dergisi 14/2 (2013): 407-425.

Aktaş, Hamza. "Akademik Güdülenme İle Akademik Özyeterlik Arasındaki İlişki: İlahiyat Fakültesi Öğrencileri Üzerine Ampirik Bir Araştırma". İnsan ve Toplum Bilimleri Dergisi 6/3 (2017): 1376-1398.

Aydın, Muhammed Şevki. Cumhuriyet Döneminde Din Ĕ̆itimi Öğretmeni Yetiştirme ve İstihdamı (1923-1998). Kayseri: İlahiyat Bilimleri Araştırma Vakfı Yayını, 2000.

Ayhan, Halis. Türkiye'de Din Eğitimi. 3. Baskı. İstanbul: Dem Yayınları, 2014.

Bandura, Albert. Self-efficacy: Toward A Unifying Theory Of Behaviral Change. Psychoogcal Review 84/2 (1994): 191-215.

Bandura, Albert. Self-Efficacy: The Exercise of Control. New York: W.H. Freeman and Company, 1997.

Bouffard-Bouchard, Therese. Influence Of Self-Efficacy Beliefs On Performance İn A Cognitive Task. Journal Of Social Psychology 130 (1989): 353-363.

Büyüköztürk, Şener. Sosyal Bilimler İçin Veri Analizi El Kitabı. 22. Baskı. Ankara: Pegem Akademi, 2016.

Chemers, Martin - Hu, Li-tze - Garcia, Ben F. Academic Self-Efficacy And First Year College Student Performance And Adjustment. Journal Of Educational Psychology 93/1 (2001): 55-64.

Çapa, Yeşim - Çil, Nesrin. "Öğretmen Adaylarının Öğretmenlik Mesleğine Yönelik Tutumlarının Farklı Değişkenler Açısından İncelenmesi". Hacettepe Üniversitesi Eğitim Fakültesi Dergisi 16 (2000): 13-24.

Çapri, Burhan - Çelikkaleli, Öner. "Öğretmen Adaylarının Öğretmenliğe İlişkin Tutum ve Mesleki Yeterlik İnançlarının Cinsiyet, Program ve Fakültelerine 
Göre İncelenmesi". İnönü Üniversitesi Eğitim Fakültesi Dergisi 9/15 (2008): 33-53.

Çetin, Özer. "İslami İlimler/İlahiyat Fakültesi Öğrencilerinin Öğretmenlik Mesleğine Yönelik Tutumlarının İncelenmesi (Uşak Üniversitesi Örneği)". Hitit Üniversitesi İlahiyat Fakültesi Dergisi 16/32 (2017): 411-432.

Durmuşoğlu, Mine Canan - Akkoyunlu, Buket - Yanık, Canan. "Türk ve Azeri Öğretmen Adaylarının Öğretmenlik Mesleğine Yönelik Tutumları". Hacettepe Üniversitesi Ĕ̆itim Fakültesi Dergisi 36 (2009): 76-86.

Gizir, Cem Ali Akbay, Sinem Evin. "Cinsiyete Göre Üniversite Öğrencilerinde Aademik Erteleme Davranışı: Akademik Güdülenme, Akademik Özyeterlik ve Akademik Yükleme Stillerinin Rolü". Mersin Üniversitesi Ĕ̆itim Fakültesi Dergisi 6/1 (2010): 60-78.

Gürbüz, Hasan - Kışoğlu, Mustafa. "Tezsiz Yüksek Lisans Programına Devam Eden Fen-Edebiyat ve Eğitim Fakültesi Öğrencilerinin Öğretmenlik Mesleğine Yönelik Tutumları (Atatürk Üniversitesi Örneği)". Erzincan Ĕ̆itim Fakültesi Dergisi 9/2 (2007): 71-83.

Kağıtçıbaşı, Çiğdem. Günümüzde İnsan ve İnsanlar. İstanbul: Evrim Yayınevi, 2008.

Kandemir, Mehmet. Akademik Erteleme Davranışını Açıklayııı Bir Model. Yayınlanmamış Doktora Tezi, Gazi Üniversitesi, 2010.

OMüifD Karasar, Niyazi. Bilimsel Araştırma Yöntemi. 17. Basım. Ankara: Nobel Yayıncılık, 2007.

Memişoğlu, Salih Paşa. "Nasıl Bir Öğretmen". Ortaöğretim Yeniden Yapılanma Sempozyumu Bildiriler Kitabı. Ankara: MEB Talim Terbiye Kurulu Başkanlığı, 2006.

Nakip, Can Özcan, Gülsen. "Öğretmen Adaylarının Öğretmenlik Mesleğine Yönelik Özyeterlik İnançları ile Öğretmenlik Mesleğine Yönelik Tutumları Arasındaki İlişki". Mersin Üniversitesi Eğitim Fakültesi Dergisi 12/3 (2016): 783795.

Özben, Şuheda. "Tezsiz Yüksek Lisans Öğrencilerinin Öğretmenlik Mesleğine İlişkin Tutumlarının İncelenmesi". D.E.Ü. Buca Eğitim Fakültesi Dergisi 1 (2010): 37-43.

Özder, Hasan - Konedralı, Güner - Zeki, Canan Perkan. "Öğretmen Adaylarının Öğretmenlik Mesleğine Yönelik Tutumlarının Çeşitli Değişkenler Açısından İncelenmesi". Kuram ve Uygulamada Eğitim Yönetimi 16/2 (2010): 253275.

Recepoğlu, Ergün. "Öğretmen Adaylarının Yaşam Doyumları İle Öğretmenlik Mesleğine Yönelik Tutumları". Hacettepe Üniversitesi Ĕ̆itim Fakültesi Dergisi Özel Say1 1 (2013): 311-326.

Sakız, Gönül. "Başarıda Anahtar Kelime: Özyeterlik". Uludă̆ Üniversitesi Eğitim Fakültesi Dergisi 26/1 (2013): 185-209. 
ILAHIYAT FAKÜLTESi ÖĞRENCILERININ ÖĞRETMENLIK MESLEĞINE ILIŞKIN

TUTUMLARI ILE AKADEMIK ÖZYETERLIK ALGILARI: SINOP ÖRNEĞi

Schunk, Dale H. "Self-Efficacy And Academic Motivaton". Educational Psychologst 26/ 3-4 (1991): 207-231.

Tanrı̈ğen, Abdurrahman. "Buca Eğitim Fakültesi Öğrencilerinin Öğretmenlik Mesleğine Yönelik Tutumları". Pamukkale Üniversitesi Ĕ̆itim Fakültesi Dergisi 3/3 (1997): 55-67.

Varış, Fatma. Eğitimde Program Geliştirme: Teori ve Teknikler. Ankara: A.Ü. Eğitim Bilimleri Fakültesi Yayınları, 1988.

Yeşilyurt, Ethem. "Öğretmen Adaylarının Öğretmen Özyeterlik Algıları". Elektronik Sosyal Bilimler Dergisi 12/45 (2013): 88-104.

Yılmaz, Miraç - Gürçay, Deniz - Ekici, Gülay. "Akademik Özyeterlik Ölçeğinin Türkçe'ye Uyarlanması". Hacettepe Üniversitesi Eğitim Fakültesi Dergisi 33 (2007): 253-259.

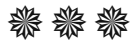

